\title{
Factors Affecting the Innaccuracy of Outpatient Disease Diagnosis Coding in General Surgery and Neurosurgery Polyclinics, Hospital X, Badung Regency
}

\author{
Ni Luh Eka Septiari Suriawan*, Bambang Hadi Kartiko, Budhimuljono Adhiwirawan \\ *Correspondent Author: ekaseptiarisuriawan@gmail.com \\ *Department of Medical Record and Health Information, University of Dhyana Pura
}

\begin{tabular}{l}
\hline I N D E X I N G \\
\hline Keywords: \\
Innacuracy Factors; \\
Disease Diagnose- \\
Coding; \\
Coders;
\end{tabular}

\begin{tabular}{l}
\hline A B S T R A C T \\
\hline The purpose of this research was to investigate the correlation of coder's comprehension, audit \\
implementation, medical record the completeness, SOP implementation, as well as facilities and \\
infrastructure completeness with the innaccuracy of outpatient diagnosis coding in General Surgery \\
and Neurosurgery Polyclinics, Hospital X, Badung Regency. This research was quantitative analytic \\
research with cross sectional study design. A total of 8 coders were sampled and as many as 200 \\
medical records were selected for the determination of coding innaccuracy. The results showed that \\
most medical records are inaccurately coded. The bivariate test using spearman's rho indicated that \\
there was a correlation between the coder's comprehension (sig. $=0.000)$, audit implementation (sig. \\
$=0.003)$, medical record completeness (sig. $=0.000$ ), SOP implementation (sig. $=0.004)$, as well as \\
facilities and infrastructure completeness (sig. $=0.000)$ with the innaccuracy of outpatient disease \\
diagnosis coding.
\end{tabular}

Kata Kunci:

Faktor Ketidakakuratan; Pengkodean Diagnosis-

Penyakit;

Koder;

Tujuan penelitian ini adalah untuk mengetahui hubungan pemahaman koder, pelaksanaan audit, kelengkapan rekam medis, pelaksanaan SOP, dan kelengkapan sarana dan prasarana dengan ketidakakuratan pengkodean diagnosis penyakit pasien rawat jalan di Poli Bedah Umum \& Poli Bedah Saraf, Rumah Sakit X, Kabupaten Badung. Penelitian ini merupakan penelitian analitik kuantitatif dengan rancangan penelitian cross sectional. Sebanyak 8 orang koder dijadikan sebagai sampel dan sebanyak 200 rekam medis dipilih untuk penentuan ketidakakuratan pengkodean diagnosis penyakit. Hasil penelitian menunjukkan bahwa sebagian besar rekam medis terkode secara tidak akurat. Uji bivariat menggunakan spearman's rho menunjukkan bahwa terdapat hubungan antara pemahaman koder (nilai sig. $=0,000$ ), pelaksanaan audit (nilai sig. $=0,003$ ), kelengkapan rekam medis (nilai sig. $=0,000$ ), pelaksanaan SOP (nilai sig. $=0,004$ ), dan kelengkapan sarana dan prasarana (nilai sig. $=0,000$ ) dengan ketidakakuratan pengkodean diagnosis penyakit pasien.

(C) 2017 JMMR. All rights reserved

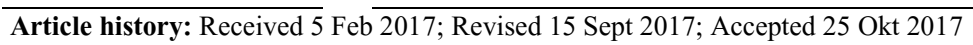

\section{INTRODUCTION}

The disease diagnosis coding is an activity in establishing proper disease and action codes based on the 10th revision of the International Statistical Classification of Diseases and Related Health Problems (ICD-10). ${ }^{1}$ This activity is one of the important things in the provision of health information written in the medical record. Recording, data collection, and information retrieval activities in accordance with the necessary diagnosis or surgery are greatly facilitated by the results of the disease diagnosis coding. Coding result can also facilitate the entry of data into available computer databases since one code may represent some of the terminology used by doctors. The disease diagnosis coding activity in the hospital is performed by the coder which is part of the medical record profession and health information (SK-Menteri Kesehatan No.-377/MenKes/SK/III/2007). ${ }^{2}$

The disease diagnosis coding is used to convert the disease diagnosis into codes consisting of letters and numbers making it easier to process the hospital report. If the disease diagnosis inaccurately encoded, the resulting information has a low data validation rate. ${ }^{8}$ In addition, inaccuracy of disease diagnosis coding can affect the reporting activities and it can cause errors in policy and decision making by hospitals and Public Health Offices. ${ }^{4}$

The inaccuracy of disease diagnosis coding are influenced by various factors. Coder's error is the most decisive factor. These errors include: (1) errors in reading the diagnosis contained in the medical record (caused by incomplete medical records), (2) errors in determining the main diagnosis made by the doctor, (3) error in determining the diagnosis code or action code, and (4) error in rewriting 
or inserting code into the computer Abdelhak et al., 2001. Characteristics of the coder that affect the accuracy of the resulting code namely: Educational background, experience and duration of work, and related training that has been experienced.

The other factors are also involved in the process of the inaccuracy of disease diagnosis. These factors include: the doctors who write the diagnosis and procedures performed, medical record completeness, facilities and infrastructure of coding, As well as coding policies issued by hospitals; Yuliani, 2010; Nuryati, 2014; Janah, $2015{ }^{6}$

The result of the preliminary observation on 50 medical records in General Surgery and Neurosurgery Polyclinics, Hospital X, Badung regency, there were 37 inaccurate medical records (74\%), and 13 accurate medical records $(26 \%)$. Furthermore, from 37 inaccurate medical records, 10 medical records $(27.02 \%)$ came from the coding by doctors, 27 medical records $(37.84 \%)$ came from the coding by nurses.

Several studies related to patient's disease diagnosis coding in hospital have been done previously Yuliani, 2010; Arifianto, 2011; Rohman, 2011; Ifalahma, 2013; Saputro \& Nuryati, 2015. However, these studies are still limited to the determination of the accuracy of disease diagnosis coding, and not specifically examined the relationship of factors causing inaccuracy of disease diagnosis coding.

This study aims to investigate the relationship of coder's comprehension, audit implementation, medical record completeness, SOP implementation, as well as facilities and infrastructures completeness with the innaccuracy of outpatient diagnosis coding in General Surgery and Neurosurgery Polyclinics, Hospital X, Badung Regency. The results of this study are expected to provide insight on the factors causing innaccuracy of outpatient diagnosis coding and provide input to the hospital for improvement that can ultimately improve the community service.

\section{RESEARCH METHOD}

This research used quantitative approach with cross sectional study design. It was started from May to June 2017 at General Surgery and Neurosurgery Polyclinics, Hospital X, Badung Regency. Eight nurses were gathered as samples using purposive sampling technique. The determination of disease diagnosis coding innaccuracy was conducted by investigating as many as 200 medical records. The innaccuracy of disease diagnosis coding was characterized by: (1) incompletely medical records filling,
(2) incorrectly medical records documenting, and (3) unwritten and uncoded primary and secondary diagnoses. The independent variables in this study were: the coder's comprehension, the implementation of medical record audit, the completeness of the medical record, the implementation of SOP, and the completeness of facilities and infrastructure.

While the dependent variable was the inaccuracy of disease diagnosis coding. The independent variable was measured by interview method using questionnaire. While the dependent variable is measured by direct observation method on medical record. Direct interviews were also conducted on the Head of Medical Record Installation to strengthen the research results. Data from each variable was presented descriptively. The relationship between independent variables and dependent variable was analyzed using Spearman's Rho test with significance level of 0.05 .

\section{RESULT AND DISCUSSION}

\section{Diagnosis Coding Process}

The disease diagnosis coding in General Surgery and Neurosurgery Polyclinics, Hospital X, Badung Regency was fully conducted by nurses who served on that two polyclinics. This was confirmed by the result of direct interview with the Head of Medical Record Installation who said that there was no specific coder in both polyclinics. Based on the direct observation, the coding diagnosis process in General Surgery and Neurosurgery Polyclinics was started from the arrival of patients and they queued up in the waiting room. The patients were then summoned according to the queue number and checked by the assigned doctor. The doctor determined the diagnosis and wrote it on the medical record (sometimes assisted by the coder). Afterwards, the coder inserted the diagnosis and its codes in the system. The diagnosis codes were not written manually. Since the contents of the medical record have been inputted in the system, the medical record was stored on the central storage.

\section{Inaccuracy of Disease Diagnosis Coding}

The frequency distribution of outpatient disease diagnosis coding in General Surgery and Neurosurgery Polyclinics, Hospital X, Badung Regency is shown in Table 1. It can be seen that most of coders encode the disease diagnosis inaccurately. The amount of medical records with inaccurate disease diagnosis code were 121 pieces $(60.5 \%)$, while the amount of medical records with accurate disease 
diagnosis code were 79 pieces (39.5\%). From the table, it also can be seen that the coders at General Surgery
Polyclinic produce higher disease diagnosis code than the coders at Neurosurgery Polyclinic.

Table 1. The frequency distribution of outpatient disease diagnosis coding in Hospital X, Badung Regency

\begin{tabular}{|c|c|c|c|c|c|}
\hline \multirow{3}{*}{ Polyclinic } & \multirow{3}{*}{ Coder } & \multicolumn{4}{|c|}{ Disease Diagnosis Code } \\
\hline & & \multicolumn{2}{|c|}{ Accurate } & \multicolumn{2}{|c|}{ Inaccurate } \\
\hline & & Frequency & Percentage & Frequency & Percentage \\
\hline \multirow{4}{*}{ General Surgery } & Coder 1 & 8 & $4.00 \%$ & 17 & $8.50 \%$ \\
\hline & Coder 2 & 9 & $4.50 \%$ & 16 & $8.00 \%$ \\
\hline & Coder 3 & 9 & $4.50 \%$ & 16 & $8.00 \%$ \\
\hline & Coder 4 & 8 & $4.00 \%$ & 17 & $8.50 \%$ \\
\hline \multirow{5}{*}{ Neurosurgery } & Coder 5 & 17 & $8.50 \%$ & 8 & $4.00 \%$ \\
\hline & Coder 6 & 10 & $5.00 \%$ & 15 & $7.50 \%$ \\
\hline & Coder 7 & 9 & $4.50 \%$ & 16 & $8.00 \%$ \\
\hline & Coder 8 & 9 & $4.50 \%$ & 16 & $8.00 \%$ \\
\hline & Total & 79 & $39.50 \%$ & 121 & $60.50 \%$ \\
\hline
\end{tabular}

\section{Coder's Comprehension}

Comprehension is the ability of a person to understand about something after he knows abaut that thing and put it on his mind. A person is said comprehend if he understands about something and can see it in various ways (Sudijono, 2009). In this study, Coder's Comprehension is the understanding of nurses who are assigned to encode the disease diagnosis in General Surgery and Neurosurgery Polyclinics, Hospital X, Badung Regency. The frequency distribution of Coder's Comprehension is shown in Table 2.

Tabel 2. The frequency distribution of coder's comprehension

\begin{tabular}{lcc}
\hline Criteria & Frequency & Percentage \\
\hline Comprehend & 1 & $12.5 \%$ \\
Uncomprehend & 7 & $87.5 \%$ \\
Total & 8 & $100 \%$
\end{tabular}

Based on Table 2, it can be seen that most of the coders have the criteria of uncomprehend namely 7 people (87.5\%). The result of direct observation and interview with Head of Medical Record Installation, revealed that health personnel assigned to encode disease diagnosis were nurses who served in the two polyclinics. This may caused the inaccuracy of disease diagnosis coding. This result is supported by research conducted by Widjaya and Rumana (2014), which stated that of the 24 coders in several hospitals in Jakarta, as many as 15 coders encoded disease diagnosis inaccurately. It was further explained that the level of education, knowledge, and work experience of the coders may influenced the inaccuracy of disease diagnosis coding.

\section{Medical Record Audit Implementation}

Medical record audit is an activity conducted by medical service officer to examine the medical records from possible incomplete attributes. Based on the result of direct interview with Head of Medical Record Installation, medical record audit at Hospital X, Badung Regency is only done on inpatient installation once in a year. While in the outpatient installation, especially in the General Surgery and Neurosurgery Polyclinics, medical audit has never been done. Table 3 shows the frequency distribution of medical record audit implementation at General Surgery and Neurosurgery Polyclinics, Hospital X, Badung Regency. Six coders $(75 \%)$ answered the questions about the implementation of medical record audit at General Surgery and Neurosurgery Polyclinics, have the criteria insufficient and the rest of them (25\%) answered the question with good criteria.

Table 3. The frequency distribution of medical record audit implementation

\begin{tabular}{lcc}
\hline Criteria & Frequency & Percentage \\
\hline Good & 2 & $25 \%$ \\
insufficient & 6 & $75 \%$ \\
Total & 8 & $100 \%$ \\
\hline
\end{tabular}

\section{Medical Record Completeness}

Medical record completeness is the complete medical record either from the point of view of the document to the filling of all the diagnoses, the history report of the physical examination disease, the progress records, laboratory results, medical treatment or surgery, and resume. Table 4 shows the frequency distribution of medical record 
completeness in General Surgery and Neurosurgery Polyclinics, Hospital X, Badung Regency.

Table 4. The frequency distribution of medical record completeness

\begin{tabular}{lcc}
\hline Criteria & Frequency & Percentage \\
\hline Complete & 1 & $12.5 \%$ \\
Incomplete & 7 & $87.5 \%$ \\
Total & 8 & $100 \%$ \\
\hline
\end{tabular}

Based on Table 4, it can be seen that most of coders namely 7 people $(87.5 \%)$ said that the medical records in General Surgery and Neurosurgery Polyclinics have incomplete criteria and the rest i.e. 1 person $(12.5 \%)$ said that medical records in General Surgery and Neurosurgery Polyclinics have complete criteria.

\section{SOP Implementation}

Based on coding Standard Operating Procedure (SOP) of Hospital X, Badung Regency, the purpose of coding are: (1) facilitate the presentation of information to support the function of planning, management, and health research and (2) uniform names and classes of diseases and operations, injuries, symptoms, and factors affecting health. The coding SOP currently used in Hospital X, Badung Regency is the 2nd revised (2016).

Table 5. The frequency distribution of SOP implementation

\begin{tabular}{lcc}
\hline Criteria & Frequency & Percentage \\
\hline Good & 1 & $12.5 \%$ \\
insufficient & 7 & $87.5 \%$ \\
Total & 8 & $100 \%$ \\
\hline
\end{tabular}

Table 5 shows the frequency distribution of SOP implementation in General Surgery and the Neurosurgery Polyclinics. It can be seen that most of coders i.e. 7 people $(87.5 \%)$ said that the implementation of SOP in General Surgery and the Neurosurgery Polyclinics have insufficient criteria and the rest of the coder i.e. 1 person (12.5\%) said that the implementation of SOP has good criteria.

\section{Facilities and Infrastructure Completeness}

Facilities and infrastructure are the tools used to encode the diagnosis of the disease, including: writing materials, computer \& printer, basic tabulation list, medical record form, and ICD books. While infrastructure include: buildings, storage shelves, and technical instructions of medical records. Table 6 shows the frequency distribution of facilities and infrastructure in General Surgery and Neurosurgery Polyclinics. Based on Table 6, it can be seen that all coders i.e. 8 people $(100 \%)$ said that the facilities and infrastructure in General Surgery and Neurosurgery Polyclinics are incomplete. The result of direct interview with the Head of Medical Record Installation, stated that it is true that the facilities and infrastructure of coding in General Surgery and Neurosurgery Polyclinics were incomplete.

Table 6. Frequency distribution of facilities and infrastructure

\begin{tabular}{lcc}
\hline Criteria & Frequency & Percentage \\
\hline Complete & 0 & $0 \%$ \\
Incomplete & 8 & $100 \%$ \\
Total & 8 & $100 \%$ \\
\hline
\end{tabular}

\section{Bivariate Statistical Test}

Bivariate statistical test was used to examine the relationship between variables. Among several bivariate tests, Spearman's rho test was choosen since some variable data were non-normal distributed. The test of data normality was conducted using Shapiro-Wilk test because the amount of sample less than 30 . The result of normality test us shown in Table 7.

Table 7. Result of normality test using Shapiro-Wilk test

\begin{tabular}{lcl}
\hline Variables & Sig. & Interpretation \\
\hline $\begin{array}{l}\text { Coder's } \\
\text { comprehension }\end{array}$ & 0,040 & Non normal \\
$\begin{array}{l}\text { Audit implementation } \\
\text { Medical record }\end{array}$ & 0,002 & Non normal \\
$\begin{array}{l}\text { completeness } \\
\text { SOP implementation }\end{array}$ & 0,156 & Normal \\
$\begin{array}{l}\text { Facilities and } \\
\text { infrastructures }\end{array}$ & 0,114 & Normal \\
$\begin{array}{l}\text { Innaccuracy of disease } \\
\text { diagnosis coding }\end{array}$ & 0,228 & Non normal \\
\hline
\end{tabular}

Based on the result of bivariate test using Spearman's rho (Table 8), it can be seen that all the relationships between independent and dependent variables have sig. value $<0.05$. This indicates that the there is a very strong relationship between the the coder's comprehension, audit implementation, medical record completeness, SOP implementation, as well as facilities and infrastructures with the innaccuracy of outpatient diagnosis coding in 
General Surgery Neurosurgery Polyclinics, Hospital X , Badung Regency. The high correlation coefficient value (close to 1) of each relationship reveals that the relationship between variables is very strong.

Table 8. Result of bivariate test using Spearman's rho

\begin{tabular}{llc}
\hline & Spearman's rho & Innaccuracy of disease diagnosis coding \\
\hline \multirow{2}{*}{ Coder's comprehension } & Correlation Coefficient & 0.975 \\
& Sig. (2-tailed) & 0.000 \\
Audit implementation & Correlation Coefficient & 0.893 \\
& Sig. (2-tailed) & 0.003 \\
Medical record completeness & Correlation Coefficient & 0.975 \\
& Sig. (2-tailed) & 0.000 \\
SOP implementation & Correlation Coefficient & 0.878 \\
& Sig. (2-tailed) & 0.004 \\
Facilities and infrastructures & Correlation Coefficient & 0.994 \\
& Sig. (2-tailed) & 0.000 \\
\hline
\end{tabular}

\section{CONCLUSION}

Based on the research, It can be concluded that most of disease diagnosis in General Surgery Neurosurgery Polyclinics, Hospital X , Badung Regency were encoded inaccurately. Bivariate analysis using Spearman's rho showed that there was a relationship between between the coder's comprehension, audit implementation, medical record completeness, implementation of SOP, as well as facilities and infrastructures with the innaccuracy of outpatient diagnosis coding.

The limitations of this research were lack of research time and the small amount of samples, so that the data errors became relatively high. There are some attempts that can be suggested to reduce the innaccuracy of diagnosis coding i.e: (1) conducting a meeting on coding discussions on outpatient installations; (2) improving coder's comprehension through coding training; (3) conducting a medical record audit at least once a year; and (4) complementing the facilities and infrastructure in the outpatient installations.

\section{REFERENCES}

1. Nuryati. (2014). Evaluasi Ketepatan Diagnosis Dan Tindakan di Rumah Sakit Panti Rapih Yogyakarta Pada Penerapan Jaminan Kesehatan Nasional (JKN). Jurnal Manajemen Informasi Kesehatan Indonesia, 3(1), 16-25.

2. Surat Keputusan Menteri Kesehatan Nomor 377/MenKes/SK/III/2007 tentang standar profesi perekam medis dan informasi kesehatan
3. Mandels, R. J. dan Calvin, L. (2014). Tingkat Akurasi Kodefikasi Morbiditas Rawat Inap Guna Menunjang Akurasi Pelaporan Di Bagian Rekam Medis Rumah Sakit Cahya Kawaluyan. Jurnal Kesehatan Caring and Enthusiasm. 2(1).

4. Arifianto, E., Kresnowati, L. dan Ernawati, D. (2011). Keakuratan Kode Diagnosis Utama Dokumen Rekam Medis Pada Kasus Partus Dengan Sectio Cesarean di Rumah Sakit Panti Wilasa Citarum Tahun 2009. Jurnal Visikes, 10(2), 84-88.

5. Abdelhak, M., Grostick, S., Hanken, M. A. and Jacobs, E. B. (2001). Health Information of A Strategic Resource. 2nd Edition. Philadelphia: Sunders Company.

6. Farzandipour, M. and Sheikhtaheri, A. (2009). Evaluation of Factors Influencing Accuracy of Principal Procedure Coding Based on ICD-9-CM: An Iranian Study. Perspectives in Health Information Management, 6(5), 1-16.

7. Ifalahma, D., 2013. Hubungan Pengetahuan Coder Dengan Keakuratan Kode Diagnosis Pasien Rawat Inap Jaminan Kesehatan Masyarakat Berdasarkan ICD-10 di RSUD Simo Boyolali. Infokes (jurnal Ilmiah Rekam Medis dan Informatika Kesehatan), 3(2), 14-26.

8. Janah, F. M. (2015). Hubungan Kualifikasi Coder Dengan Keakuratan Kode Diagnosis Rawat Jalan Berdasarkan ICD-10 di RSPAU dr. S. Hardjolukito Yogyakarta. Skripsi, Universitas Muhammadiyah Surakarta. 
9. Pramono, A. E. (2012). Hubungan Antara Coder (Dokter Dan Perawat) dengan Keakuratan Kode Diagnosis Berdasarkan ICD-10 di Puskesmas Gondokusuman II Kota Yogyakarta Tahun 2012. Skripsi, Universitas Muhammadiyah Surakarta.

10. Rohman, H., Hariyono, W. dan Rosyidah (2011). Kebijakan Pengisian Diagnosis Utama dan Keakuratan Kode Diagnosis Pada Rekam Medis di Rumah Sakit PKU Muhammadiyah Yogyakarta. Jurnal Kesmas, 5(2), 162-232.

11. Saputro, N. T. dan Nuryati (2015). Faktor Penyebab Ketidaktepatan Kode Diagnosis di Puskesmas Mojolaban Sukoharjo Jawa Tengah. Jurnal Manajemen Informasi Kesehatan Indonesia, 3(1), 5964.

12. Sudijono, A. (2009). Pengantar Statistik Pendidikan. Jakarta: Rajawali Press.

13. Widjaya, L. dan Rumana, N. A. (2014). Faktor-Faktor Yang Mempengaruhi Keakurasian Koding Ibu Melahirkan dan Bayi di Beberapa Rumah Sakit Tahun 2014. Skripsi. Universitas Esa Unggul.

14. Yuliani, N. (2010). Analisis Keakuratan Kode Diagnosis Penyakit Commotio Cerebri Pasien Rawat Inap Berdasarkan ICD-10 Rekam Medik di Rumah Sakit Islam Klaten. Infokes (Jurnal Ilmiah Rekam Medis dan Informatika Kesehatan), 1(1), 17-31. 